\title{
PENGARUH MANAJEMEN PENDIDIKAN ISLAM DAN SUMBER DAYA GURU AQIDAH AKHLAK TERHADAP PRESTASI BELAJAR SISWA PADA MATA PELAJARAN AQIDAH AKHLAK DI MTs SE-KABUPATEN BANJARMASIN
}

\author{
Tamjidnor \\ UIN Antasari Banjarmasin \\ tamjidnor@uin-antasari.ac.id
}

\begin{abstract}
ABSTRACK
Recent social trends or phenomena that have occurred in society which have implications for the demands and expectations of future educational models. The reality on the ground shows that teacher professionalism is still inadequate. This is one of the factors for low learning achievement. This paper describes the Influence of Islamic Education Management and Aqidah Akhlak Teacher Resources on Student Achievement in Aqidah Akhlak Subjects. The subjects of this study were Aqidah Akhlak teachers and students of State and Private Madrasah Tsanawiyah Banjarmasin City Regency. This research was conducted using a descriptive method with a quantitative approach. The collection of data regarding the management of Islamic education and the resources of aqidah morality teachers was carried out through the distribution of questionnaires. Data was collected through a questionnaire from 81 respondents as a total sample of 69 State and Private Madrasah Tsanawiyah Banjarmasin City Regency. Student learning achievements in subjects were taken from report scores and then averaged per school. The data was processed using the SPSS 17 program for windows. Islam and the resources of teachers of aqidah morals tend to have higher levels of student achievement in the subjects of aqidah morality. In connection with the results of the research above, suggestions are given (1). it is necessary to increase knowledge and understanding of Islamic education management as an effort to improve student learning achievement so that students avoid moral degradation. (2). it is necessary to make efforts to increase the resources of Aqidah Akhlak teachers through training to increase teacher competence, because the resources possessed by teachers affect the low and high quality of education. (3). For further researchers, it is recommended to conduct research with a wider scope of material, the development of research variables and a deeper study.
\end{abstract} Keyword: aqidah morals, management, resources, achievements

\section{ABSTRAK}

Kecenderungan atau gejala sosial baru yang terjadi di masyarakat akhir-akhir ini yang berimplikasi pada tuntutan dan harapan model pendidikan masa depan. Kenyataan di lapangan memperlihatkan profesional guru masih belum memadai. Hal ini yang menjadi salah satu faktor rendahnya prestasi beljar. Tulisan ini menggambarkan Pengaruh Manajemen Pendidikan Islam dan Sumber Daya Guru Aqidah Akhlak terhadap Prestasi Belajar Siswa Pada Mata pelajaran Aqidah Akhlak. Subjek penelitian ini adalah guru-guru Aqidah Akhlak dan Siswa Madrasah Tsanawiyah Negeri dan Swasta se- Kota Banjarmasin. Penelitian ini dilakukan dengan menggunakan metode deskriptif dengan pendekatan kuantitatif. Pengumpulan data mengenai manajemen pendidikan Islam dan sumber daya guru aqidah akhlakl dilakukan melalui penyebaran angket. Data terkumpul melalui angket dari 81 responden sebagai sampel total dari 69 Madrasah Tsanawiyah Negeri dan Swasta se- Kota Banjarmasin. Prestasi belajar siswa pada mata pelajaran di ambil dari nilai laport kemudian dirata-ratakan per sekolah. Data diolah dengan menggunakan program SPSS 17 for wimdows. Berdasarkan analisis hasil penelitian atas dapat ditarik kesimpulan yaitu Manajemen Pendidikan Islam dan sumber daya guru aqidah akhlak secara bersama-sama berpengaruh positif dan signifikan terhadap prestasi belajar siswa pada mata pelajaran aqidah akhlak, artinya semakin baik manajemen pendidikan islam dan sumber daya guru aqidah akhlak cenderung semakin tinggi tingkat prestasi belajar 


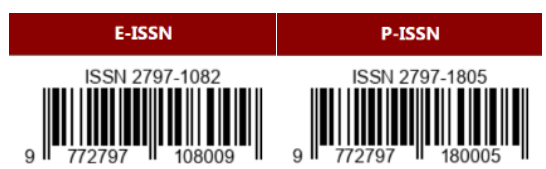

siswa pada mata pelajaran aqidah akhlak. Sehubungan dengan hasil penelitian di atas, disampaikan saransaran (1). diperlukan peningkatan pengetahuan dan pemahaman tentang manajemen pendidikan Islam sebagai upaya dalam meningkatkan prestasi belajar siswa sehingga siswa terhindar dari terjadinya degradasi moral. (2). perlu adanya upaya-upaya peningkatan sumber daya guru Aqidah Akhlak melalui pelatihanpelatihan peningkatan kompetensi guru, karena sumber daya yang dimiliki guru berpengaruh terhadap rendah tingginya mutu pendidikan. (3). Bagi peneliti selanjutnya disarankan untuk melakukan penelitian dengan cakupan materi yang lebih luas, pengembangan variabel-variabel penelitian dan pengkajian yang lebih dalam.

Kata kunci: aqidah akhlak, manajemen, sumber daya, prestasi

\section{PENDAHULUAN}

Pendidikan merupakan instrumen penting yang akan menunjukan kualitas sumber daya manusia sebuah bangsa. Salah satu faktor untuk meningkatkan kualitas hidup bangsa Indonesia adalah dengan meningkatkan kualitas pendidikan. Peningkatan kualitas mutu pendidikan merupakan komitmen untuk meningkatkan sumber daya manusia, baik sebagai pribadipribadi maupun sebagai modal dasar pembangunan.

Undang-Undang Dasar 1945 telah mengamanatkan tentang pentingnya pendidikan bagi seluruh warga negara Indonesia yang menguraikan bahwa "Setiap warga negara berhak atas pendidikan yang layak". Dalam pasal 1 angka 1 UndangUndang Nomor 20 Tahun 2003 tentang Sistem Pendidikan Nasional, dijelaskan bahwa: Pendidikan adalah usaha sadar dan terencana untuk mewujudkan suasana belajar dan proses pembelajaran agar peserta didik secara aktif mengembangkan potensi dirinya untuk memiliki kekuatan spiritual keagamaan, pengendalian diri, kepribadiaan, kecerdasan, akhlak mulia, serta keterampilan yang diperlukan dirinya, masyarakat, bangsa, dan negara. Tujuan pendidikan dalam Undangundang Sistem Pendidikan Nasional No: 20 tahun 2003, Bab 2, Pasal 3 menyebutkan bahwa, Pendidikan nasional bertujuan untuk berkembangnya potensi anak didik agar menjadi manusia yang beriman dan bertaqwa kepada Tuhan yang maha esa, berakhlak mulia, sehat, berilmu, cakap, kreatif, mandiri dan menjadi warga negara yang demokratis serta bertanggungjawab.

\section{TINJAUAN PUSTAKA}

Dalam pencapaian tujuan pendidikan dibuat sistem pendidikan secara Nasional. Sistem Pendidikan Nasional adalah satu keseluruhan yang terpadu dari semua satuan dan kegiatan pendidikan yang berkaitan satu dengan yang lainnya, untuk mengusahakan tercapainya tujuan pendidikan nasional.

Salah satu tujuan pendidikan nasional adalah berkembangnya potensi anak didik agar menjadi manusia yang beriman dan ketaqwaan terhadap Tuhan Yang Maha Esa. Salah satu upaya untuk meningkatkan keimanan dan ketaqwaan terhadap Tuhan Yang Maha Esa dapat diwujudkan melalui pendidikan agama. Dengan demikian lembaga-lembaga pendidikan agama Islam yang menjadi garapan Direktorat Jenderal Kelembagaan Agama Islam termasuk di dalamnya lembaga pendidikan Madrasah Tsanawiyah memiliki peran yang sangat strategis dalam mewujudkan tujuan tersebut. Maka salah satu bidang studi yang harus dipelajari oleh peserta didik di Madrasah Tsanawiyah adalah pendidikan agama Islam, yang dimaksudkan untuk membentuk peserta didik menjadi manusia yang beriman dan 


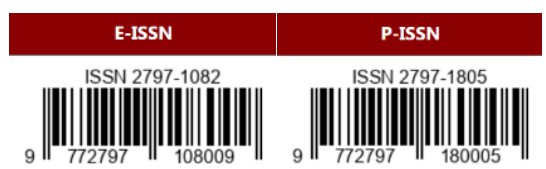

bertakwa kepada Tuhan Yang Maha Esa serta berakhlak mulia.

Pendidikan agama Islam (PAI) di Madrasah Tsanawiyah yang terdiri atas empat mata pelajaran yang memiliki karakteristik sendiri-sendiri.

Al-Qur'an-Hadist, menekankan pada kemampuan baca tulis yang baik dan benar, memahami makna secara tekstual dan kontekstual, serta mengamalkan kandungannya dalam kehidupan sehari-hari.

Aspek akidah menekankan pada kemampuan memahami dan mempertahankan keyakinan / keimanan yang benar serta menghayati dan mengamalkan nilai-nilai alasma' al-husna.

Aspek Akhlak menekankan pada pembiasaan untuk melaksanakan akhlak terpuji dan menjauhi akhlak tercela dalam kehidupan sehari-hari.

Aspek Fikih menekankan pada kemampuan cara melaksanakan ibadah dan muamalah yang benar dan baik.

Sedangkan aspek Tarikh \& kebudayaan Islam menekankan pada kemampuan mengambil ibrah dari peristiwaperistiwa bersejarah (Islam), meneladani tokohtokoh berprestasi, dan mengaitkannya dengan fenomena sosial, budaya, politik, ekonomi, IPTEK dan lain-lain untuk mengembangkan kebudayaan dan peradaban Islam.

\section{METODE}

Metode yang digunakan dalam penelitian ini adalah metode penelitian deskriptif dengan pendekatan Kuantitatif. Metode deskriptif adalah penelitian yang berusaha mendeskripsikan suatu gejala, pristiwa, kejadian yang terjadi pada saat sekarang. Berdasarkan pada pemikiran tersbut, maka metode deskriptif digunakan untuk mendapatkan data dari tempat tertentu yang alamiah (bukan buatan), dengan cara menggali sebanyak-banyaknya informasi dari berbagai sumber orang / benda sebagai bahan deskripsi.

Jenis penelitian deskriptif ini lebih terpokus pada pengungkapan hubungan sebab dan akibat (Hubungan Kausal antar Variabel), yaitu variabel bebas dan variabel terikat, yaitu pengaruh manajemen pendidikan Islam sebagai variabel bebas ke 1 (variabel X1) dan sumber daya guru mata pelajaran Aqidah Akhlak merupakan variabel bebas ke 2 (variabel X2) prestasi belajar pada mata pelajaran Aqidah Akhlak variabel terikat (variabel Y).

Berdasarkan konsep dan teori, dibangun konstruk (variabel) dan indikator yang berfungsi sebagai dasar penyusunan instrumen penelitian dalam bentuk tes dan kuisioner. Sedangkan desain penelitian yang digunakan yaitu desain korelasional, artinya data- data X1 dan X2 dikorelasikan dengan Y. Sehingga dapat menggambarkan pengaruh antara variable bebas dan variable terikat.

\section{HASIL PEMBAHASAN}

Untuk menganalisis hasil penelitian agar tidak terjadi terjadi salah pengertian, baik dilihat dari teori maupun konsep yang relevan, maka pembahasan hasil penelitian mengacu pada rumusan masalah sebagai berikut:

Pengaruh Manajemen Pendidikan Islam terhadap Prestasi Belajar Siswa pada Mata Pelajaran Aqidah Akhlak.

Dilihat dari hasil pengolahan data statistik dengan menggunakan SPSS 17 for windows, menunjukan adanya korelasi positif yang signifikan pengaruh manajemen pendidikan islam terhadap prestasi belajar siswa pada mata peajaran aqidah akhlak. Jadi dapat dinyatakan, Semakin meningkat kemampuan manajemen pendidikan islam guru aqidah akhlak maka semakin meningkat 


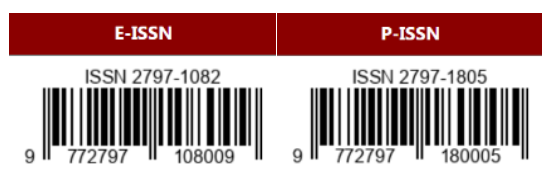

nilai rata-rata aqidah akhlak (prestasi), maka hifotesis pertama dinyatakan signifikan atau dapat diterima.

\section{Sumber Daya Guru Aqidah Akhlak terhadap Prestasi Belajar Siswa pada Mata Pelajaran Aqidah Akhlak}

Dilihat dari hasil pengolahan data statistik dengan menggunakan SPSS 17 for windows, menunjukan adanya korelasi positif yang signifikan pengaruh Sumber daya guru Aqidah akhlak terhadap prestasi belajar siswa pada mata peajaran aqidah akhlak. Jadi dapat dinyatakan, Semakin meningkat sumber daya guru Aqidah akhlak maka semakin meningkat nilai rata-rata aqidah akhlak (prestasi), maka hifotesis kedua dinyatakan signifikan atau dapat diterima.

\section{Manajemen Pendidikan Islam dan Sumber Daya Guru Aqidah Akhlak terhadap Prestasi Belajar Siswa Pada Mata Pelajaran Aqidah Akhlak.}

Dilihat dari hasil pengolahan data statistik dengan menggunakan SPSS 17 for windows, menunjukan adanya korelasi positif yang signifikan pengaruh Manajemen Pendidkan Islam dan Sumber daya guru Aqidah akhlak terhadap prestasi belajar siswa pada mata peajaran aqidah akhlak. Jadi dapat dinyatakan, semakin meningkat manajemen pendidikan Islam dan sumber daya guru Aqidah akhlak maka semakin meningkat nilai rata-rata aqidah akhlak (prestasi), maka hifotesis ketiga dinyatakan signifikan atau dapat diterima.

\section{KESIMPULAN}

Berdasarkan hasil penelitian yang telah diuraikan pada bab sebelumnya, maka dapat ditarik simpulan bahwa pengaruh Manajemen pendidikan Islam dan sumber daya guru aqidah akhlak terhadap prestasi belajar siswa pada mata pelajaran aqidah akhlak di Madrasah Tsanawiyah Negeri dan
Swasta Se-Kabupaten Banjarmasin, sebagai berikut:

1) Ada pengaruh positif dan signifian antara manajemen pendidikan Islam terhadap prestasi belajar siswa pada mata pelajaran Aqidah Akhlak di Madrasah Tsanawiyah Negeri dan Swasta Se-Kabupaten Banjarmasin. Hal tersebut bermakna semakin tinggi skor Manajemen Pendidikan Islam maka semakin tinggi skor prestasi belajar siswa pada mata pelajaran Aqidah Akhlak.

2) Ada pengaruh positif dan signifikan antara sumber daya guru Aqidah Akhlak terhadap prestasi belajar siswa pada mata pelajaran Aqidah Akhlak di Madrasah Tsanawiyah Negeri dan Swasta Se-Kabupaten Banjarmasin.. Hal tersebut bermakna semakin tinggi skor Sumber daya guru Aqidah Akhlak maka semakin tinggi skor prestasi belajar siswa pada mata pelajaran Aqidah Akhlak.

3) Ada pengaruh positif dan signifikan antara manajemen pendidikan Islam dan sumber daya guru Aqidah Akhlak terhadap prestasi belajar siswa pada mata pelajaran Aqidah Akhlak di Madrasah Tsanawiyah Negeri dan Swasta Se-Kabupaten Banjarmasin. Hal tersebut bermakna semakin tinggi skor manajemen pendidikan Islam dan sumber daya guru Aqidah Akhlak maka semakin tinggi skor prestasi belajar siswa pada mata pelajaran Aqidah Akhlak.

\section{DAFTAR PUSTAKA}

Departemen Agama RI (2005). Pedoman Standar Pelayanan Minimal Madrasah Aliyah. 
Eka Yuda Wibawa, A. (2021). Hubungan Kepemimpinan Kepala Madrasah Dan Prestasi Kerja Guru Dengan Kemajuan Madrasah Aliyah SeKabupaten Surakarta. Berajah Journal, $1(1)$, $56-63$.

https://doi.org/10.47353/bj.v1i1.20

Fauzan. (2010). Ensiklopedi Pendidikan Islam

Bagian 3. Sukamajaya Depok: CV. Binamuda Ciptakreasi.

Fauzan. (2010). Ensiklopedi Pendidikan Islam

Bagian 6. Sukamajaya Depok: CV. Binamuda ciptakreasi.

Koswara, Adun Rusyana, Ade Yeti

Nuryantini. (2008) Manajemen

Strategi Dalam Pengembangan

Sisitem Pendidikan. Ciamis:

SS.PRES.

Nafis, Ahmad Syukron. (2011). Manajemen

Pendidikan Islam. Yogyakarta.

LaksBang PRESSindo.

Permadi Dadi, Arifin Daeng. (2007)

Kepemimpinan Transformasional Kepala Sekolah dan Komite Sekolah. Bandung: PT. Sarana Pasca Karya Nusa.

R, R. (2021). Manajemen Pendidikan Pondok Pesantren Al Falah Banjarbaru Di Masa

Pandemi Covid-19. Berajah Journal, 1(2), 64-71.

https://doi.org/10.47353/bj.v1i2.7

Saud, Udin S. (2011). Pengembangan Profesi Guru. Bandung: Alfabet.

Syarifuddin (2005). Pengelolaan Madrasah.

Bandung: Pusat Studi Pesantren dan Madrasah (PSPM)

Syafaruddin (2005). Manajemen Lembaga Pendidikan Islam. Jakarta: PT. Ciputat Press.

Saud Udin S, Sutarsih Cicih. (2012). DasarDasar Manajemen Sumber Daya Manusia. Bahan Ajar Perkuliahan MSDM.
Undang-Undang Guru dan Dosen. (2006). Bandung: Fokusmedia.

Widodo, Sembodo Ardi. (2003). Kajian Filosofis Pendidikan Barat dan Islam. PT. Rakasta Samasta. 